\title{
THE DEVELOPMENT OF THE SPA IN SEVENTEENTH-CENTURY FRANCE
}

\author{
L. W. B. Brockliss
}

THE ESTABLISHMENT OF THE SPA

In the Anglo-Saxon world the enthusiasm of the twentieth-century Frenchman for imbibing his country's mineral waters is proverbial. It is surprising, therefore, to discover that the French contribution to the resuscitation of the spa in the era of the Renaissance was minimal. For most of the sixteenth century, the nation that has given mankind the waters of Vichy and Evian (to name but two) was largely unmoved by the fad for the hot-spring and the mineral bath that swept the Italian peninsula, crossed the Alps into the territory of the Holy Roman Empire, and penetrated even our own shores. It was not that France's future spas were undiscovered, for many had a Romano-Gallic provenance. It was rather that the therapeutic potential of mineral waters remained unrecognized by the Galenic medical establishment and hence by the large majority of the court, aristocracy, and urban élite who formed their clients. Significantly, when Andreas Baccius published the first general guide to the spas of Europe in 1571 he had little to say about France. Passing reference was made to several Roman foundations but only the virtues of Bourbon-Lancy were described in detail. ${ }^{1}$ Significantly, too, the only member of the French royal family who definitely did take the waters in the first three-quarters of the sixteenth century was united by marriage to the house of Navarre and patronized, as did her daughter later, the springs of Béarn, not those of France. ${ }^{2}$

The situation first began to change in the 1580 s when a number of local physicians started to promote the waters adjacent to the towns in which they plied their profession. Their inspiration, it would seem, came largely (although not entirely) from a change of heart at court. Much of the impetus for the development of the spa north of the Alps was provided by Paracelsians, whose interest in metallic and arcane remedies drew them ineluctably to the mineral spring. Most Paracelsians, however, were Protestants or Erasmian eirenicists above the religious divides of the day and it was only in the reign of the politique Henri III (1574-89) that they surfaced at the Catholic Valois court and began to influence medical opinion close to the royal

L. W. B. Brockliss, Magdalen College, Oxford OX1 4AU.

All quotations in the text and titles cited in the notes follow the original orthography. Wherever possible the dates of a physician are given when he is first referred to.

\footnotetext{
${ }_{1}^{1}$ A. Baccius, De thermis . . Libri septem, Venice, apud Vincentium Valgrisium, 1571, esp. pp. 226-7.

2 Nancy Roelker, Queen of Navarre. Jeanne d'Albret 1528-1572, Cambridge, Mass., Harvard University Press, 1968, pp. 47, 83, 159, 195. Margaret of Angoulême, Queen of Navarre visited Cauterets for the first time in 1541 .
} 


\section{W. B. Brockliss}

family. In the persons of the King and Queen they found a ready audience, for the royal couple had failed to produce a child and the House of Valois was in danger of extinction. ${ }^{3}$ Understandably, the royal couple was ready to snatch at any therapeutic straw which promised fecundity. In 1580, therefore, when the king's doctors advised

FRENCH AND BEARNESE SPAS IN THE EARLY-MODERN ERA

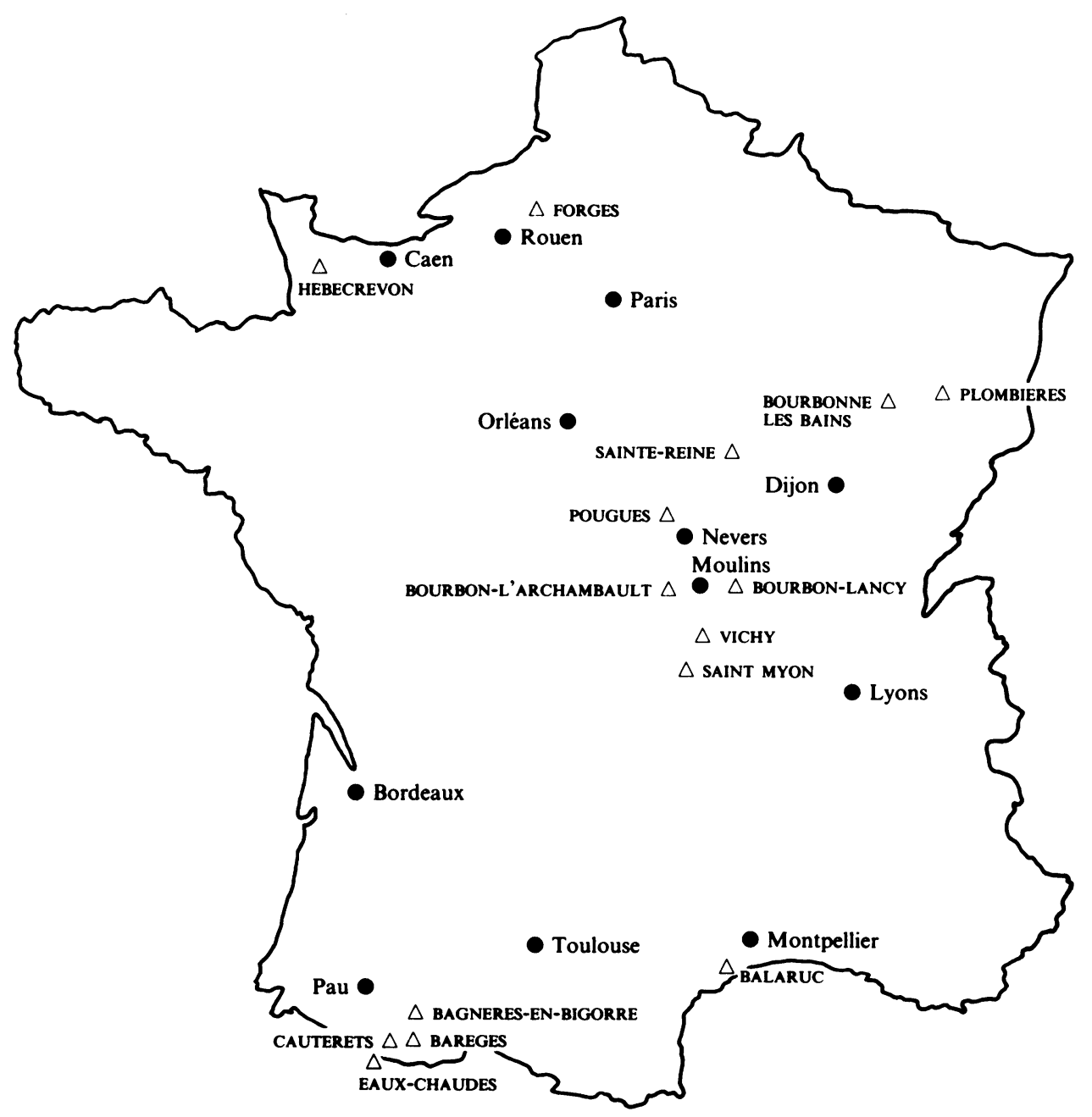

Key

- Principal Towns

$\triangle$ SPAS

NB. Until the 1730s Plombières was part of the independent Duchy of Lorraine.

${ }^{3}$ The king did have a childless younger brother who died in 1584. 
that their majesties take the waters for the health of the dynasty, the royal patients did not demur. Moreover, the king, for reasons unknown (perhaps it was a question of honour) chose to visit a French station: Bourbon-Lancy. At that date the Bourbon spa was a noble ruin and little definite was known about the waters' properties. In consequence, the king dispatched his chief physician, Miron, with his chief architect and the controller of the royal buildings,

affin de rechercher plus particulierement les singularités, et remettre aucunement l'ancienne commodité des Bains accablés et confondus dans leurs ruines, destoupper les canaux, $\tan$ des fontaines que de la vuidange desdicts Bains, ou deja la longueur du temps avoit ensevely le nom avec la forme de la chose. ${ }^{4}$

Given both the parlous state of the spa and its former grandeur (the bath had been roofed) Miron's commission was a tall order. Nevertheless, with 150 men at his behest he hastily made the spa usable, erecting among other things a house where the bathers could stay. The king and queen then duly arrived attended by numerous sick courtiers and proceeded to "take the waters". Thereafter the future of the French spa was assured, if not the future of the House of Valois. The queen failed to get pregnant, this fate being reserved instead for another member of the royal party, the 54-year-old Comtesse de Fiasque. ${ }^{5}$

In the final two decades of the sixteenth century there is plenty of evidence that spas were being "discovered" and promoted all over France. Indeed, so well-established had the practice of "taking the waters" become by the turn of the seventeenth century that enthusiastic spa physicians became eager to maximize their earnings by drawing their clients from a wider provenance than the immediate locality. In a flurry of pamphlets and books they trumpeted the virtues of their particular source to the wider world in the obvious hope that physicians elsewhere in France and Europe would point a clutch of clients in their direction. The first such publication appeared as early as 1579 when Nicolas Dortomann (d. 1596), professor of medicine at Montpellier, produced a book puffing the virtues of the waters of Balaruc, proof that one faculty at least was taking an interest in the new therapy before it received the royal seal of approval. ${ }^{6}$ But the large majority of pamphlets appeared only around 1600 , once the spa was socially respectable. The techniques of promotion were largely the same. The authors began by extolling the virtues of mineral waters tout court, then proceeded to describe the peculiar efficacy of their local spring whose wonders they could attest from personal experience. One spa, at Pougues near Nevers, was even championed in

\footnotetext{
${ }^{4}$ Jean Auberi, Les Bains de Bourbon-Lancy et Larchambaut, Paris, chez Adrian Perier, 1605, p. 55r. Auberi gives a good description of the extent and spendour of the Roman baths in chs. $v$-vi.

5 Ibid., p. 55v. In 1585 Henri III took the waters again, this time at the famous springs of Spa in the Spanish Netherlands: presumably his enthusiasm for things French had waned in the interim: see C. L. von Poellnitz, Amusemens des Eaux de Spa, 2 vols., Amsterdam, Pierre Mortier, 1734, vol. 1, pp. $286-7$.

${ }^{6}$ N. Dortomannus, Libri duo de causis et effectibus thermarum Belilucanarum, parvo intervallo a Monspeliensi urbe distantium, Lyon, apud C. Pesnot, 1579. Balaruc may have been the first French spa to be exploited by the medical profession in the last quarter of the sixteenth century. Interestingly, Montaigne made no reference to French spas in his journal of his voyage to Germany and Italy, although "taking the waters" played an important part in his itinerary. Nor had Montaigne visited a French spa prior to his journey of 1580-81, although he had been to the spas of Béarn. See Montaigne, Journal de voyage, ed. Louis Lautrey, Paris, Hachette, 1906, pp. 19-20. Béarn at the date was an independent kingdom.
} 


\section{W. B. Brockliss}

verse. Raimond de Massac, dean of the medical college at Orléans, published a lengthy Latin encomium to the fountain $\dot{a}$ la Ovid in 1597 that was then translated into French verse by his son, Charles, and reprinted in 1605. Pougues, like so many other French spas, was apparently an old foundation, now dilapidated, whose medicinal qualities were far above those of the vaunted springs of Italy and Germany. Its purgative waters, if not, admittedly, good for all, were particularly beneficial for sufferers from the stone.

J'y vis une Driade image de la Mort

Martire en la langueur qui la minoit si fort,

Elle avoit, ô grand mal! la pierre en vessie,

Qui par signes nous fut et par sonde eclaircie,

Mais aprez avoir beu de se sacré bouillon

Cette pierre fondit en flegme et en sablon,

Qui, graveleux, au chaud du soleil en sa course

S'empierroient de rechef et tesmoignent leur source, ...7

Despite such assiduous promotion, however, most of the new spas of the turn of the seventeenth century were not destined for a spectacular future. Admittedly, most would survive until at least the Revolution, but only a handful would acquire the national and international reputation their supporters avidly hoped for. In fact, in the second half of the seventeenth century, it would seem that only three-Bourbonl'Archambault, Vichy, and Forges-were consistently patronized by the great and the good. ${ }^{8}$ At some time in their lives virtually every member of the court of Louis XIV (except the king himself) seems to have visited at least one of these spas. The king's mistress, for example, Mme de Montespan, was a regular visitor at Bourbon. Courtiers went anywhere else only if they believed that a different source would be particularly beneficial in the case of an extraordinary malady. Thus, the Duc de Maine, bastard son of La Montespan and the king, was forced to endure on several occasions $(1675,1677$, and 1681) the long journey south to the Pyrenean resort of Barèges. Lame to the point of being unable to walk and suffering from a weeping fistula, the young boy, it was felt, would respond only to the waters of Béarn. ${ }^{9}$

The reason for the spectacular popularity of Bourbon, Vichy, and Forges had nothing to do with their propinquity to Paris and the now sedentary court. Forges may be only 113 kilometres from the capital, but Bourbon and Vichy are far from Paris and in the seventeenth century could be reached only after a lengthy journey. In 1676 it took Mme de Sévigné, travelling in her personal coach, a full eight days to cover the distance to Vichy. ${ }^{10}$ It was a journey, moreover, that could be extremely arduous when the weather was inclement. Eleven years later, now over 60 , Mme de

${ }^{7}$ Les Fontenes de Pougues de Mre Raimond de Massac, French translation by Charles de Massac, Paris, chez Toussaincts du Bray, 1605, pp. 40-1.

${ }^{8} \mathrm{~A}$ list of late eighteenth-century stations can be found in Bibliothèque de la Faculté de Médecine, Paris, MS 2220.

9 Mme de Maintenon, Lettres, ed. Marcel Langlois, vol. 2, Paris, Letouzey \& Ané, 1935, pp. 75-80, 136, 233-9, 384-402.

${ }^{10}$ Mme de Sévigné, Lettres de Madame de Sévigné, de sa famille et de ses amis, ed. M. Monmerque, 14 vols., Paris, Hachette, 1862, vol. 4, pp. 442-53. 
Sévigné took the waters once more, this time at Bourbon. Travelling in late September, she decided unwisely to take the direct route from Nevers to Bourbon, rather than go via Moulins. The conditions she encountered over the 14-league journey were atrocious: "nous marchâmes depuis la pointe du jour jusques à la nuit fermée, sans arrêter que deux heures justes pour dîner; une pluie continuelle, des chemins endiablés, toujours à pied, de peur de verser dans des ornières effroyables [i.e., she had to alight]". ${ }^{11}$ Not surprisingly, some of the quality preferred to travel as far as possible by barge, although this must have increased the length of the journey considerably. Thus Mme de Montespan, at Bourbon in 1676, travelled back to meet the king at Fontevraud-l'Abbaye via the Allier and the Loire, taking ship at Moulins. $^{12}$

Nor, irrespective of the hazards of the journey, were these three spas particularly attractive because of their location or facilities. Like most French stations the three were located on the outskirts of modest towns-cum-villages. Even in the mideighteenth century these towns remained small and unprepossessing. Bourbon in 1762 was a bourg of 240 feux or 2,000 inhabitants; Forges at the same date boasted 148 feux taillables and one feu privilègié. ${ }^{13}$ Good and ample accommodation, then, was not easy to find. There were a few hôtels devoted specifically to those taking the waters, but most visitors must have lodged with the villagers. The poet Boileau, at Bourbon in 1687 , stayed with a master-surgeon. ${ }^{14}$ Only those who enjoyed the delights of the countryside (not a noticeable seventeenth-century trait among people of quality) were likely to find such locations charming. Thus Mme de Sévigné may have gone into bucolic raptures in describing the environs of Vichy, but the classical Boileau described Bourbon as "le plus vilain lieu du monde". ${ }^{15}$ Not surprisingly, furthermore, none of these three spas was a notorious centre of conspicuous consumption, as we shall see. Life there was singularly routinized and monotonous: these were no Baths or Baden-Badens avant la lettre.

What drew people to these three spas in particular was quite simply their reputation as centres of healing. Enthusiastic promoters of their waters would tend to claim that there were few diseases that could not be cured by visiting one or other of the three. ${ }^{16}$ On the whole, though, popular wisdom and the medical establishment were more discerning. Forges was the haven of the nephritic and the infertile; Vichy and

11 Ibid., vol. 8, pp. 98-9.

12 Ibid., vol. 4, p. 483.

13 J. J. Expilly, Dictionnaire géographique, historique et politique des Gaules et de la France, 6 vols., Paris, Desaint \& Saillant, 1762, vol. 1, p. 730; vol. 3, pp. 323-4. I have no figures for the seventeenth century.

${ }^{14}$ Boileau, Oeuvres complètes, ed. Antoine Adam, Paris, Gallimard, 1966, p. 1206, n. 4. The hôtel at Bourbon occupied by Mme de Montespan and Mme de Sévigné still survives.

${ }^{15}$ Sévigné, op. cit., note 10 above, vol. 4, pp. 461, 474: letters to her daughter, 20 May and 1 June 1676; Boileau, op. cit., note 14 above, p. 743: letter to Racine, 13 August 1687. Mme de Maintenon's opinion of the delights of Barèges was just as jaundiced: see Maintenon, op. cit., note 9 above, pp. 138-9: letter to her brother, 8 July 1675 .

${ }^{16} \mathrm{Cf}$. for instance the claims for Forges in J. Larouvière, Nouveau système des eaux minerales de Forges, Paris, chez Laurent d'Houry, 1699, pt. ii. Admittedly, not all spa doctors asserted that their local spring was a cure-all: e.g., Isaac Cattier, De la nature des bains de Bourbon, et des abus qui se commettent à présent en la boisson de ces Eaux, Paris, chez Pierre David, 1650, especially the blandishments in the avant-propos. 


\section{W. B. Brockliss}

Bourbon, the resort of the paralytic and the apoplectic. It was to Forges, therefore, that Louis XIII and Anne of Austria were directed in the 1630s as another royal couple desperately sought an heir, this time with more success. ${ }^{17}$ It was to the Bourbonnais, on the other hand, that Mme de Sévigné wound her way in 1676, when an attack of rheumatism at the age of 50 left her unable to bend her fingers and hence in the intolerable position (for her) of being unable to hold a pen. Similarly, it was to Bourbon that Boileau travelled in 1687 when, to the dismay of himself and his friends, the great wit and raconteur had unaccountably lost his voice. ${ }^{18}$

It is hard to believe, however, that this was a reputation based upon a significantly higher number of successful cures than that achieved at rival spas. Admittedly, in a pre-statistical age hearsay and personal recommendation counted for much. When Mme de Sévigné returned from Vichy extremely satisfied with her progress, she immediately promoted the waters' virtues among her acquaintances. ${ }^{19}$ Nonetheless, the pamphlet literature suggests every spa boasted its bevy of cures. If three in particular gained a reputation for healing the abused bodies of persons of quality, this can only have occurred by means of an intermediary force, a guiding hand which encouraged the ailing rich to absorb the lessons of experience in one location rather than in another. This guiding hand, it must be stressed, was not the hand of God. No one ever suggested that Forges, Vichy, and Bourbon were the sites of miraculous intervention. As God was the creator of all parts of nature, He was, of course, the creator of their healing waters. But in this respect God was to be found in any spa. ${ }^{20}$ Rather, the guiding hand was a decidedly human one.

In the final analysis, what guaranteed that three spas above all would flourish was the strategic position of their original promoters. In the beginning, at the turn of the seventeenth century, spas in France were promoted by local physicians who saw their potential as centres of therapy and profit. Most local physicians were just that: local men with few contacts beyond the immediate region. Dortomann was a professor of Montpellier; Jacques de Cahaignes (1548-c.1620), who promoted the waters of Hebecrevon, a professor at Caen. ${ }^{21}$ A handful of physicians, however, had the money, the contacts, and the good sense to gain positions at court. Once there, they were in a peculiarly advantageous position for promoting their local spa. Not only could they freely point their royal clients and hence the court in the direction of their native waters; they could also manipulate the minds of the Parisian robe and haute bourgeoisie. Through the very fact that they were physicians at court, such doctors had the right to practise in the capital city without becoming members of the Paris

\footnotetext{
17 The king and queen visited Forges together in 1633, although the future Louis XIV was not born until 1638 (some sources wrongly have 1631 or 1632 ).

18 This was accounted a nervous disorder. Boileau had little faith in his physician's diagnosis, believing that his loss of voice stemmed from the chest complaint that he had had for 25 years: see Boileau, op. cit., note 14 above, pp. 734-5: letter to Racine, 26 May 1687.

${ }_{19}$ Sévigné, op. cit., note 10 above, vol. 4, p. 506: letter to her daughter, 1 July 1676.

${ }^{20}$ Galenists in the early seventeenth century did talk of springs having an occult, "divine" quality, but they meant by this a quality not rationally comprehensible. If Christians in earlier centuries had attributed cures at certain springs to the intervening agency of saints (as the common names of many springs suggested), then this reflected their ignorance of "occult" nature. E.g., Auberi, op. cit., note 4 above, ch. 13.

21 Jacques de Cahaignes, De aqua fontis Hebrecrevonii praelectio habita in scholis academiae Cadomensis ... 1612, Caen, ex typographia J. Bassi, n.d.
} 
college. ${ }^{22}$ In other words, Vichy, Forges, and Bourbon became the dominant spas of the seventeenth century through the assiduous lobbying of interested parties exploiting their professional position to the maximum advantage. In a highly hierarchical and relatively centralized society, it was very easy for a few strategicallyplaced individuals to play the role of opinion-formers.

The power of a single individual is perfectly illustrated in the case of Bourbonl'Archambault. This was the second of two neighbouring spas which bore the name of the royal house after 1589 , but the one on first sight less likely to flourish. In the first place, unlike Bourbon-Lancy, it was not a Gallo-Roman foundation, but dated only from the time of St Louis. Its founder, purportedly, was the local count, father of Béatrice de Bourbon, the king's daughter-in-law. ${ }^{23}$ In consequence, in the late sixteenth century the spa had inevitably none of the grandeur, albeit a ruined grandeur, of Bourbon-Lancy. ${ }^{24}$ In addition, it had not been to Bourbon-l'Archambault that the court had travelled in 1580. Not surprisingly, therefore, at the turn of the seventeenth century Bourbon-Lancy was the spa in the more flourishing condition. Through the efforts of two Moulins physicians, it had been the scene of "des succés si merveilleux que non seulement la France, mais la pluspart de l'Europe, les publie et redit souvent". ${ }^{25}$

By the mid-seventeenth century, however, the position had changed and Bourbonl'Archambault was the spa "plus visitez et recherchez". The reason, according to a contemporary, was that its waters were "estimez plus temperez". ${ }^{26}$ But this was to neglect the vital role in the promotion of Bourbon-l'Archambault played by one Charles Delorme (1584-1678), médecin ordinaire du roi. Charles, a Montpellier graduate in $1608,{ }^{27}$ was the son of Jean Delorme, who in the early seventeenth century was physician to the wife of Henri IV, Marie de Médicis. Charles thus had an easy entrée to the court and for some 40 years after 1610 was personal physician to several members of the royal family including Louis XIII's brother, Gaston d'Orléans, whose premier médecin he became in 1629 . He was also heir to his father's interest in Bourbon-Lancy, for Jean Delorme was one of the two Moulins doctors who had supposedly put the spa on the European map. For some reason or other, however,

\footnotetext{
${ }^{22}$ In the larger towns of seventeenth-century France only members of the local college of physicians had the legal right to practise medicine. In Paris membership was the automatic result of becoming a doctor in the Paris faculty of medicine. But this was an expensive and time-consuming business and there were seldom more than 100 to 120 faculty physicians in the capital throughout the century. Not surprisingly, the Paris college objected to the ease with which court doctors (by an arrêt of the Paris Parlement of 1597) could breach its monopoly and there were continual quarrels between the two: see L. W. B. Brockliss, 'La querelle entre les facultés de médecine de Paris et Montpellier au dix-septième siècle' (a paper given to the Colloque historique pour le VIF Centenaire de l'Université de Montpellier (1289-1989), Montpellier, October 1989. The proceedings of the conference are to be published). The latest account of the organization of the medical profession in early modern France is given in Matthew Ramsey, Professional and popular medicine in France 1770-1830. The social world of medical practice, Cambridge University Press, 1988, ch. i.

${ }_{23}$ Auberi, op. cit., note 4 above, p. $61 \mathrm{v}$.

${ }^{24} \mathrm{Cf}$. the descriptions of the two spas at the turn of the seventeenth century given in ibid., bk. i., chs. v, vi and $x$.

25 Ibid., p. 56r.

${ }^{26}$ Cattier, op. cit., note 16 above, p. 23.

${ }^{27}$ The printed abstracts of his bachelor's, licentiate's, and doctor's dissertations (the last sustained 1-4 October, 1608) can be found in the British Library, Printed Books, $1180 \mathrm{~b}(1)$.
} 


\section{W. B. Brockliss}

Charles decided to use his influence to promote the rival station at Bourbonl'Archambault. ${ }^{28}$ This he did throughout his long working life with a single-minded enthusiasm and ruthlessness that became proverbial. No one doubted that Delorme profited hugely from promoting the spa. According to Tallement des Réaux, Delorme was even accused "d'avoir pris pension des habitans pour y faire aller bien du monde". ${ }^{29}$ Whatever the truth of the matter, Delorme definitely gave the waters of Bourbon-l'Archambault their reputation in high society. On his death, after 50 years of careful promotion, their future was assured, all the more since at the end of the seventeenth century their efficacy was further confirmed by the king's chief physician, Guy-Crescent Fagon (1638-1718). ${ }^{30}$ The latter, in charge of the king's body from 1693 to 1715 , was a particularly influential figure at court in matters of health. Unlike chief physicians before him, Fagon seems to have had an absolute authority over other court medical men and their clients. The fact then, that he favoured Bourbon and also Forges and Vichy, was as vital for the survival of the country's three leading spas at the turn of the eighteenth century as their earnest promotion by court doctors like Delorme had been for their original pre-emimence. ${ }^{31}$

\section{THE SPA AS AN INSTITUTION}

French spas in the seventeenth century can be divided into two types: hot springs where the visitors could both drink and bathe, and cold springs where patients were normally allowed only to imbibe the waters. Vichy and Bourbon belonged to the first category; Forges the second. ${ }^{32}$ Each spa had its peculiar season, dependent on its latitude and height above sea-level. Generally, however, there was little activity before May and the season was over by early October (the season at Forges ran only from 1 July to 15 September). A study of a random sample of the many manuals devoted to "taking the waters" in seventeenth-century France suggests that the approved procedure was virtually the same at every station. Initially derived from established practice in Italy, this procedure was introduced at the beginning of the century by the first generation of spa doctors and continued thereafter with only minor modifications. Whatever the spa, the course of treatment began and ended in the same manner. First of all patients had to be bled and purged in order to open the pores and permit an easier evacuation of the morbid humours. This, one expert believed, could be most comfortably done at home, but could only be done at the

\footnotetext{
${ }^{28}$ Possibly because he had been granted the intendancy of the waters there. For this office, see below. For biographical notices on Delorme father and son, see: Michaud, Biographie universelle, vol. 10, pp. 345-6; Dictionnaire de biographie franfaise, vol. 10, cols. 884, 886-7; the details are not absolutely correct.

29 Tallement des Réaux, Les historiettes, ed. G. Mongrédien, 8 vols., Paris, Garnier, [1932-4], vol. 4, pp. 180-2.

30 J. Pascal, Traité des Eaux de Bourbon l'Archambaud selon les principes de la nouvelle physique, Paris, chez Laurent d'Houry, 1699, dedication [to Fagon], aiii.

${ }^{31}$ For Fagon's "tyranny" of court medicine (Saint-Simon's phrase), see L. W. B. Brockliss, 'The literary image of the Médecins du Roi in the literature of the Grand Siècle', in V. Nutton (ed.), Medicine at the courts of Europe 1500-1837, Wellcome Institute Series in the History of Medicine, London and New York, Routledge, 1990, pp. 117-54.

32 People did occasionally bathe in the waters of Forges but there was no permanent bath: Mme de Pontchartrain did so in 1707: example cited in Saint-Simon, Mémoires, ed. Gonzague Truc, 7 vols., Paris, Gallimard, 1963-70, vol. 2, 915.
} 


\section{The spa in seventeenth-century France}

source if the patient had travelled a long distance. Patients were also usually purged at the end of their stay, with a view, according to the same authority, of removing the earthy crasses left in the stomach from drinking the waters. ${ }^{33}$ Medicinal purgation in the course of the treatment was less common, but was resorted to when patients were deemed not to have sufficiently rendered the waters absorbed by drinking or bathing.

The custom when drinking the waters was to repair to the fountain at the earliest possible hour and always before the patient had broken his fast. Some spa doctors, such as Cattier at Bourbon, insisted on patients drinking at sun-up. But others, like Fouet at Vichy, were more relaxed, and felt that the hour should be a moveable feast according to the patient's habits. Sleep patterns should not be disturbed, so the rich and idle should attend the fountain at a more civilized hour. ${ }^{34}$ As the fountains were uncovered, this advice must have been music to the ears of those who attended in the early or late season. The amount of time spent at the spring was seldom more than an hour and patients were encouraged, if possible, to drink the waters while walking about (so that they might be rendered more easily). The number of glasses consumed depended on the fountain. The three springs at Forges were deemed to have a violent purgative effect, so imbibers were limited to three to four glasses at the beginning. Rending Bourbon water, however, was judged more difficult, so over a three-week stay patients would increase their dose to as many as 20 glasses per day. ${ }^{35}$ After finishing their allotted number of glasses, the imbibers would next spend several hours promenading in the vicinity of the fountain until they had rendered as far as possible an equivalent amount of waste (either in urine or faeces). Most stations provided for this purpose a shaded alleee, usually to be found attached to a Capuchin convent. ${ }^{36}$ As can be imagined a morning spent in this fashion was far from pleasant, even for seventeenth-century patients generally used to consuming noxious and dramatic purgatives. Mme de Sévigné, as always, has left the most graphic, if laconic, description of the experience (while drinking the waters of Vichy).

On va à six heures à la fontaine: tout le monde s'y trouve, on boit et l'on fait une forte vilaine mine; car imaginez-vous qu'elles sont bouillantes, et d'un goût de salpêtre fort désagréable. On tourne, on va, on vient, on se promène, on entend la messe, on rend les eaux, on parle confidemment de la manière qu'on les rend: il n'est question de cela jusqu'à midi. ${ }^{37}$

33 Larouvière, op. cit., note 16 above, pp. 179-80, 208.

34 Cattier, op. cit., note 16 above, p. 126; Claude Fouet, Le Secret des bains et eaux-minérales de Vichy en Bourbonnois, Paris, chez la veuve d'Olivier de Varennes, 1679, p. 113. Larouvière, op. cit., note 16 above, p. 188, also suggested a more leisurely start.

${ }^{35}$ Ibid., pp. 186-7; Cattier, op. cit., note 16 above, p. 130. It is, of course, very difficult to compare the quantities advised at different fountains given the vagueness of the term "glass". Even when specific measurements are referred to, it must be remembered that there was no uniformity in the weights and measures used in the different French provinces. According to an anonymous author, the maximum amount of Forges water that should be consumed was seven pints for men and three to four for women: see Bibliothèque Nationale, MS 2037, 'Traité des Eaux minérales de Forges' (1697), fol. 33r. The waters of cold springs were sometimes warmed before drinking: see Larouvière, op. cit., note 16 above, pp. 192-3.

36 The Capuchins established convents and public walks at virtually all French spas. Their role in the development of balneology in France and elsewhere needs exploring. The best description so far encountered of their activities at a mineral spring is to be found in Poellnitz, op. cit., note 5 above, vol. 1, passim: Capuchin walks may only have been accessible to male patients (ibid., p. 63).

${ }^{37}$ Sévigné, op. cit., note 10 above, vol. 4, p. 456: letter to her daughter, 20 May 1676. 


\section{W. B. Brockliss}

The sick who repaired to stations where the waters could be taken externally as well as internally had the choice of several forms of therapy. All such spas had one or more mineral baths in which the patient would be daily immersed for varying lengths of time. But most spas from the beginning of the century had also some sort of vapour room or étuve where the patient could absorb the fumes given off by the spring, and some form of shower mechanism whereby a jet of water could be sprayed directly on the injured part. Each form of immersion could be used separately or in combination with drinking the waters, but a course in none of the three was ever begun until the patient had imbibed several days at the fountain. The victim, it was believed, had first to be thoroughly purged internally by the waters, so that their external application could be truly effective. In this case the therapy worked not by releasing the morbid humour through the bowel or the bladder but by its excretion through sweat. At the end of a session, therefore, usually an hour, the patient was carefully wrapped in hot blankets and transferred to a bed where he would lie for several hours sweating profusely. Sometimes, according to Cattier, the patient would there be given mineral water to drink in order that he would sweat the more. ${ }^{38}$ Sometimes, too, excretion would be encouraged by mudpacks or scarification, although the latter was not deployed as wantonly as it had been at Baden in the late sixteenth century. ${ }^{39}$

The public baths of the early seventeenth-century French spa were relatively crude affairs. There is little evidence that new baths were built initially, so most were Roman or medieval in origin. If divided from the outside world by a surrounding wall, they were usually open to the air (hence the limited season), unisex, and socially mixed (even where there was more than one bath). Sometimes the bottom was not even tiled. This was the case at Bourbon-l'Archambault, where the larger bath (supposedly capable of taking 150 people) was filled by springs located in the mud floor. ${ }^{40}$ Improvements seem to have occurred only in the second half of the century, when some attempt was made to cater for the sensitivities of the quality bather by housing the chief bath in a proper building and creating alternative facilities for the socially less respectable. Cattier in 1650 felt that there was no need to describe the baths at Bourbon because this had already been done by Auberi in 1605. By 1699, however, when Pascal published an account of the spa, the topography was very different. A building called the maison du roi (now a museum) covered the original twin-bath, while three new constructions fed by water from the drinking wells had been erected in the vicinity: one, called the charity bath, for the poor. ${ }^{41}$

Bathing, understandably, occurred later in the day than drinking. Cattier suggested two hours after sun-up, but Fouet insisted only on some time in the morning. ${ }^{42}$ On beginning their treatment, bathers were supposed to immerse themselves for no more than half an hour, but the time spent in the water was gradually increased until the

\footnotetext{
${ }^{38}$ Cattier, op. cit., note 16 above, p. 141.

${ }^{39}$ Montaigne, op. cit., note 6 above, p. 87. At Baden in Switzerland the baths ran with blood. Cattier, op. cit., note 16 above, p. 146, suggested cupping after the bath.

${ }^{40}$ Auberi, op. cit., note 4 above, p. 63r. The two baths joined together had an area of 8 by 20 pas (p. 65v).

${ }^{41}$ Cattier, op. cit., note 16 above, p. 24; Pascal, op. cit., note 30 above, ch. 3.

42 Cattier, op. cit., note 16 above, p. 136; Fouet, op. cit., note 34 above, p. 120 . Cattier also advised a short afternoon dip two to three hours before sunset.
} 


\section{The spa in seventeenth-century France}

midway point of the normal 15-day course. ${ }^{43}$ Bathers descended into the water by way of the surrounding steps and immersed themselves as far as the waist or neck, depending on the location of the injured part. Once in the water the patient was expected to stand stock still,

autrement il émoveroit par l'agitation les vapeurs de l'eau, qui luy monteroient à la teste; et receuroit plus de chaleur dans le bain, par l'abord continuel de nouvelles eaux à la peau: au lieu que le corps demeurant en repos, les eaux s'attiedissent et s'accommodent à son temperament, et ainsi le malade s'y accoustume plus facilement. ${ }^{44}$

The heat of some baths, it must be said, could be hard to endure. When the young Duc de Maine was at Barèges in 1677 he was unable to stop himself crying on initial immersion. ${ }^{45}$ At Bourbon patients were warned to expect red marks and scorching on the skin. ${ }^{46}$

Much less is known about vapour baths. There was one especially constructed at Bourbon-Lancy by 1605 through the munificence of one Beaulieu, conseiller et sécrétaire du roi. At Bourbon-l'Archambault at the same date, however, the facilities were more makeshift. An estuve was created by removing one of the iron grilles from the three drinking wells and the patient descending the shaft to two or three feet above the water level. The well-head was then closed by a hemispherical cover to protect the incumbent from the outside air. Whether the facilities became more comfortable thereafter is impossible to say. As later accounts of Bourbon-l'Archambault say nothing about vapour baths, it is possible this form of therapy went out of fashion as the century progressed. ${ }^{47}$

Plenty of information, on the other hand, exists about the shower facilities at French spas. There seem to have been two forms of administering the spray. Either the patient could be laid on a bench or he could be given the douche while immersed in the bath, although the second method, it was felt, could be applied only to the robust. In either case the patient had to suffer water from cans of different sizes being poured from a height of two to three feet on the injured part. There were several organs and parts of the body that the douche could adversely effect if improperly administered (the liver, spleen, stomach, head, etc.), so it was a therapy not to be undertaken lightly. The head had to be particularly looked after. The area around the lesion (internal or external) had to be shaved and the treatment was begun only with the

\footnotetext{
${ }^{43}$ According to Cattier, op. cit., note 16 above, p. 139, a course could extend 40 days. Mme de Sévigné had nine baths at Vichy in 1687: Sévigné, op. cit., note 10 above, vol. 8, pp. 116-17: letter to her daughter, 9 October.

44 Cattier, op. cit., note 16 above, p. 136.

${ }^{45}$ Maintenon, op. cit., note 9 above, p. 255: the duke to his mother, Mme de Montespan. He may have been taking the bath in his room. This was always possible for those unable to go to the public bath for some reason, but the water had to be fetched; in France mineral water was not piped directly to private rooms as at Baden, in Switzerland: see Montaigne, op. cit., note 6 above, p. 87.

${ }^{46}$ Cattier, op. cit., note 16 above, p. 140.

${ }^{47}$ Auberi, op. cit., note 4 above, pp. 37r, 153v-154r. But vapour baths were still used at Balaruc in the mid-eighteenth century: see Encyclopédie ou dictionnaire raisonné des sciences, des arts et des métiers, 17 vols., Paris, 1751-65, vol. 10 (1765), p. 538, col. ii.
} 


\title{
L. W. B. Brockliss
}

administration of tepid (i.e., adulterated) mineral water. Once the session (usually an hour twice a day) was over, then the patient's head had to be carefully wiped and covered with a coif and wool bonnet. Subsequently, while excreting sweat, the patient was not to get cold but also had to keep out of the sun and not go to sleep (a pleasure permitted those who had taken a mineral bath). ${ }^{48}$

One illustrious patient who suffered the douche was the Duc de Maine at Barèges. In his case the therapy was given in conjunction with his daily bath and was administered at the end of the session. This was necessary, wrote La Maintenon, for psychological rather than medical reasons. If the doctors began with the douche, then the duke's patience was quickly exhausted by the violence of the spray: "ainsy il n'en reste plus pour durer le bain". ${ }^{49}$ In contrast, the rheumatic Mme de Sévigné at Vichy in 1676 received the douche on its own:

\begin{abstract}
J'ai commencé aujourd'hui la douche: c'est une assez bonne répétition du purgatoire. On est toute nue dans un petit lieu sous terre, où l'on trouve un tuyeau de cette eau chaude, qu'une femme vous fait aller où vous voulez. Cet état où l'on conserve à peine une feuille de figuier pour tout habillement, c'est une chose assez humiliante. J'avois voulu mes deux femmes de chambre, pour voir encore quelqu'un de connoissance. Derrière le rideau se met quelqu'un qui vous soutient le courage pendant une demi-heure; c'étoit pour moi un médecin de Ganat [near Vichy] . . Représentez-vous un jet d'eau contre quelqu'une de vos pauvres parties, toute la plus bouillante que vous puissiez vous imaginer. On met d'abord l'alarme partout, pour mettre en mouvement tous les esprits; et puis on s'attache aux jointures qui one été affligées; mais quand on vient à la nuque du cou, c'est une sorte de feu et de surprise qui ne se peut comprendre... 50
\end{abstract}

Whatever the types of water therapy a French seventeenth-century spa might offer, the sick visitor could expect (in theory at least) that his treatment would be carefully supervised. Almost from the moment that the spa was resurrected in the late sixteenth century it ceased to be a private institution run by the propriétaire of the site and enterprising local physicians and came instead under state supervision. From 1605 the Crown in an arrêt of the conseil d'état decreed that every spa must be run by a medically-qualified intendant who would be appointed by the king's chief physician. ${ }^{51}$ A surviving (late seventeenth-century?) règlement for the stations of the provinces of Burgundy, the Bourbonnois, and the Auvergne makes it clear that the intendant's powers were widespread. His primary task was to discover the real properties of the mineral waters that he controlled, so that "taking the waters" would be no longer an empirical game. More important, however, was the power of patronage that the title bestowed. The intendant would name the physicians who would have the right to practise at the spa, and would appoint an appropriate number of surgeons,

\footnotetext{
${ }^{48}$ Cattier, op. cit., note 16 above, pp. 143-6. Auberi, op. cit., note 4 above, believed that the drop of the shower should be three to four feet (p. 187r).

49 Maintenon, op. cit., note 9 above, p. 385.

${ }^{50}$ Sévigné, op. cit., note 10 above, vol. 4, pp. 467-8.

51 The post seems to have been venal. Presumably the propriétaire received a percentage of the intendant's takings. I have not yet seen the original arrêt. It is referred to in royal letters patent of 7 September 1718, confirming the powers of superintendance of the then-chief physician of the king, Claude J. B. Dodart (1664-1730): Bibliothèque de le Faculté de Médecine de Paris, MS 2206, fols. 312-13.
} 
apothecaries, baigneurs, corneteurs, and other assistants. Visitors who came to take the waters were required to place themselves under the aegis of the intendant or his associates. The only people exempted were persons of the highest quality who arrived with their own physicians, or qualified physicians who came for a cure themselves. Outside physicians, though, could not treat other patients and were expected to consult with the official spa doctors. The intendant and his associates were expected to attend throughout the season. They were there both to advise and to keep order: the spa was supposed to be a quiet and decorous haven for the afflicted. A key figure in maintaining standards would be the baigneur. The latter was to make sure that the bathers always wore "un linge blanc pour garder la pudeur", and was to prevent any horse-play, evidence that not every one stood stock still in the bath. Shouting, touching, spanking, and blasphemy were all outlawed. The baigneur, too, was to keep out undesirables, part of the Crown's drive to keep the waters clean:

Et ledit baigneur en chassera absolument tous Galeux, Escrouelleux, et generalement tous infectez des vices de cuir non seulement contagieux et communicables, mais horribles et odieux a la veue et empeschera d'y laver aucuns linges soit savonnez ou lessives ny aucuns vaisseaux ou il y ait eu des liqueurs par lesquelles l'eau puisse estre en aucune facon alterez ou corrompue. ${ }^{52}$

The very existence of such a règlement, of course, emphasizes that decorum was far from universal at the French spa, even in the late seventeenth century. ${ }^{53}$ There again it is a significant document for it testifies to the close interest that the state took in this burgeoning institution. It emphasizes, too, what a sought-after position the intendancy must have been. Not surprisingly, Charles Delorme was the (somewhat absentee) intendant at Bourbon-l'Archambault. How many physicians an intendant would have employed is impossible to say. There were at least three at Bourbon in 1687: Bourdier, who had close links with the rising court star, Fagon; Des Trapieres, a client of the then-chief physician to the king, d'Aquin (1632-96); and the exProtestant Amyot (perhaps the actual intendant). ${ }^{54}$ Obviously, the size of the practice would depend on the annual number of clients, but this too is beyond our present knowledge. No account, however conjectural, has survived of the number of visitors to a French seventeenth-century spa. Given the small size of the towns in which the spas were located, it is hard to believe that even the most popular stations welcomed

\footnotetext{
52 Bibliothèque Nationale, MS Français 16741 , fols. $125 \mathrm{r}-127 \mathrm{v}$, 'Reglemens et statuts pour les eaux minerales et bains naturels de ce Royaume dressez a l'usage des Provinces d'Auvergne [,] Bourgogne, Bourbonnois et Forests; et comme les Intendans et Medecins destinez s'y doivent comporter pour la santé des malades' (no date, probably the reign of Louis XIV), esp. fol. 126v. The baigneur and other attendants were to be dressed in royal livery to emphasize the dignity of their function.

${ }_{53}$ The public baths at French spas were continually fed by spring water and the excess run off in culverts. Some, too, could be properly drained but how often this was done is not known. Even in the late eighteenth century the waters of the bath at one spa were extremely polluted: see Bibliothèque de la Faculté de Médecine, Paris, MS 5143, piece I, 'Etat actuel de la fontaine et des bains d'Eau Thermale à Bourbonne [les Bains]' [no pag.; 1782, from the papers of $\mathbf{N}$. Chambon de Montaux].

54 Information from Boileau, op. cit., note 14 above, pp. $735-50$ plus end-notes: letters to Racine (plus extracts from Racine's replies) July-September 1687. Mme de Sévigné was treated at Bourbon by Amyot. There is a bibliographical notice on Amyot (Christian name and dates unknown) in Dictionnaire de biographie francaise, vol. 3, col. 745 .
} 


\section{W. B. Brockliss}

more than 500 patients a year: housing and feeding a greater number would have been far too difficult. 55

It is easier to build up a picture of the clientele thanks to the many references to individual visitors contained in the spa guidebooks, contemporary memoirs and letters, and the court gazette. Every year in the second half of the century Bourbon, Vichy, and Forges played host to a representative cross-section of the French élite. At Bourbon in the spring and summer of 1687 were to be found not only Mme de Montespan and her entourage, but two bishops, various courtiers such as the Duc and Duchesse de Beauvilliers, a bevy of high legal and fiscal officials, and several abbots and abbesses. The quality, it seemed, came to the spa from all over France: Paris, Caen, Tours, Reims, Montauban, Brittany, and so on. ${ }^{56}$ Moreover, until the outbreak of the War of the League of Augsburg, they came, if we believe a local physician, from all over Europe ${ }^{57}$ But visitors to the most popular spas were not just taken from the top drawer. Humble bourgeois, merchants, lawyers, simple curés and an endless stream of afflicted monks and nuns came to take the waters, too. Even artisans were not unknown, such as the maitre couvreur of the rue Montergueil in Paris who visited Forges in $1697 .^{58}$ The presence of separate charity baths by the end of the century, moreover, is evidence that some of the visitors must have been very lowly indeed. Understandably, however, the truly indigent only occasionally make an appearance in the source literature and they are never named. What is clear is that the poor could only attend a flourishing spa if they were the receptacles of benevolent patronage. It is clear, too, that they were not always welcome, even when an institution (in the form of a local hospital) existed to house them. Boileau records the arrival at Bourbon of a poor paralytic sent by Mme de Montespan. The local Sisters of Charity, however, refused to accept the invalid, even when Boileau authenticated the signature on the recommendation. Boileau, anxious that the poor man should not die in the streets, gave him a room in the house where he himself lodged, "où il est traité et pansé comme moi". 59

The same sources also allow us to discover what life was like at the seventeenthcentury French spa away from the fountain and the bath. This seems to have been unremittingly dull, even by the relatively restrained contemporary standards of a "fast" existence. Having "taken" and "rendered" the waters for most of the morning, patients took or were advised to take a light dinner consisting of a soup dish followed by roasted meat. Fish, fruit (for obvious reasons), vegetables, and dairy products

\footnotetext{
55 In the mid-eighteenth century, some 12,000 visited Bath in a season: see Sylvia Macintyre, 'Towns as health and pleasure resorts: Bath, Scarborough and Weymouth 1700-1815', D. Phil. Oxford, 1973, pp. 41-3.

${ }^{56}$ From a list of around 100 prestigious visitors to Bourbon recorded in the Mercure Galante, August 1687 , p. 88. Boileau's name curiously does not appear.

${ }^{57}$ Pascal, op. cit., note 30 above, ch. 1 . English milords supposedly visited Forges in the 1690s: see Larouvière, op. cit., note 16 above, pp. 192-3 and 215, but perhaps they were exiled Jacobites.

${ }^{58}$ Larouvière, op. cit., note 16 above, p. 163 . This work is a particularly good source for studying the social background of the clientele.

${ }^{59}$ Boileau, op. cit., note 14 above, pp. 786-7: letter to his sister 31 July 1687 . The Sisters of Charity were the leading nursing order in Counter-Reformation France. They are the subject of a detailed study being undertaken by Dr Colin Jones of Exeter University. Virtually every little town in seventeenth- and eighteenth-century France had a hospital or hospice to look after the indigent sick and dying.
} 


\section{The spa in seventeenth-century France}

were all banned. ${ }^{60}$ The afternoon was given over to restful indoor leisure activities in the company of a small group of friends. Patients read, played cards, or made idle conversation. Mme de Sévigné described a typical afternoon at Vichy thus: "après dîner, on va chez quelqu'un: c'étoit aujourd'hui chez moi. Mme de Brissac [wife of a duke] a joué a l'hombre avec Saint-Hérem et Plancy [two of La Sévigné's male friends]; le chanoine [a nickname] et moi nous lisons l'Arioste; elle a l'italien dans la tête ...".61 Over-exitement was judged disadvantageous for a patient's progress, as was going to sleep. While playing cards was acceptable, gambling (which was evidently commonplace) was frowned upon by the medical experts. Heavy gains or losses could produce a movement of the spirits as great as if the patient had taken violent exercise. $^{62}$

In the late afternoon, about 5 p.m., the patients left their lodgings and in the cool of advancing evening repaired to the local promenades to take gentle exercise. According to the abbé de Marolles, who visited Forges in 1641, the exercise could be gentle indeed: he and his companions were taken for a ride in a coach. ${ }^{63}$ Such indolence, however, was probably exceptional. Mme de Sévigné definitely took to her feet at Vichy. She found, furthermore, a picturesque way to enliven her evening strolls. At Vichy, it seems, astute local peasants would perform country dances in the adjoining meadows for the edification of the persons of quality. Mme de Sévigné in a bucolic mood was enraptured and continually referred to the delights of the Auvergnese bourrée (her word) in her letters. Versailles, she believed, would be enchanted by the show; the local peasants were so much better than gypsies. Captivated, Mme de Sévigné made sure that the bourrée was a daily experience by subsidizing the musical accompaniment: "Je donne tous les soirs un violin avec un tambour de basque qui me coûte quatre sous". 64

The evening promenade, however, was not prolonged. At 7 p.m. the patients took a light supper (lighter than dinner) and withdrew from the world to write letters. By 10 p.m. everyone was in bed and the day was over. It need hardly be said that for an aristocrat, if not a bourgeois, this was an early hour to retire. In the highest circles, the evening would by then have only just begun. It was the hour of departure to a society ball or supper. But there were no such divertissements at the seventeenth-century French spa. Indeed, no evidence of junketings of any kind has come to light. Boileau seems to have contemplated giving a ball in honour of the arrival of two of his friends at Bourbon who were to share his lodgings, but this seems to have been a private reception. ${ }^{65}$ Life was certainly not one great round of the theatre, dances, and supper

\footnotetext{
60 Cattier, op. cit., note 16 above, p. 131 ; Larouvière, op. cit., note 16 above, p. 198. Mme de Sévigné dined lightly and drank "eau de poulet" each day: Sévigné, op. cit., note 10 above, vol. 4, pp. 461, 471: letters to her daughter, 24 and 28 May 1676.

${ }^{61}$ Ibid., p. 456: letter to her daughter, 20 May. She did not like to play cards for fear of falling asleep: see pp. 484-5 (11 June).

62 Larouvière, op. cit., note 16 above, p. 199.

63 Michel de Marolles, Mémoires, 2 vols., Paris, A. de Sommaville, 1656-7, vol. 1, p. 245.

64 Sévigné, op. cit., note 10 above, vol. 4, p. 483: letter to her daughter, 8 June 1676.

${ }^{65}$ Boileau, op. cit., note 14 above, p. 788: letter to his sister, 31 July 1687.
} 


\section{W. B. Brockliss}

parties as was to be the case at eighteenth-century Spa and Bath. "66 "Taking the waters" in seventeenth-century France was a serious activity: the atmosphere was more reminiscent of a hospice than a health farm.

Several reasons can be adduced for this sober lifestyle. "Taking the waters" itself was guaranteed to produce depletion and fatigue, a physical state scarcely conducive to hyper-activity and sociability. Patients, as they themselves claimed, were completely worn out by their medical experience ${ }^{67}$ But the same effects would be felt wherever in the world the sick subjected themselves to mineral-water therapy. That "taking the waters" in France had such a singularly lethargic effect is a reflection of the degree to which, in the reign of Louis XIV at any rate, most visitors to the spa followed the instructions of their medical advisors with alacrity. Although not every visitor was willing to place himself totally at the mercy of the physician, few indulged in the independent and arbitrary experiments in consumption and immersion practised by Montaigne. ${ }^{68}$ The late seventeenth-century visitor was truly a patient (a point we will come back to). Lassitude and its social effects, then, were the result of obedience to the spa physician. At the same time, of course, irrespective of their physical state, the very willingness of the French to follow ad litteram the advice of the spa physicians also encouraged visitors to order their leisure time in the prescribed manner.

Two further factors worked in the same direction. Visitors to the seventeenthcentury French spa were self-contained. They came with a ready-formed entourage in whose company they remained throughout their visit: they did not come seeking to meet new acquaintances or hatch marriage alliances. Sometimes two or three visitors travelled together as companions and then met up with other friends at the spa. Mme de Sévigné went to Vichy in the company of Mme de Brissac and to Bourbon with Mme de Chaulnes, the latter as much her nurse as her companion. ${ }^{69}$ Once at the spa she moved in a narrow circle of some half-dozen friends. Sometimes visitors came as a family group. Indeed, given the traditional picture of family relations in seventeenthcentury France, it is astonishing how many husband-and-wife pairings were to be found among the élite attending Bourbon in $1687 .^{70}$ Visitors who came on their own seemed to have lived a solitary existence. Boileau claimed that he saw virtually no one before his friend, Marchand, turned up as he was about to leave. "Je m efforce pourtant de traisner ici ma miserable vie du mieux que je puis avec un Abbé tres honneste homme qui $y$ est Tresorier $d$ une ste Chapelle mon Medecin et mon Apotiquaire ... J'ay aussi une servante."71

\footnotetext{
${ }^{66}$ Poellnitz, op. cit., note 5 above, passim, but esp. vol. 1, pp. 56-7 (a typical day), 66, 121-7, 256-7 (accounts of balls); A. Barbeau, Life and letters at Bath in the XVIII century, London, William Heinemann, 1904, esp. ch. 3.

${ }^{67} \mathrm{Cf}$. the complaints of Boileau to Racine in a letter, 19 Aug. 1676: in Boileau, op. cit., note 14 above, p. 745: the poet moaned that he was completely exhausted, had no appetite, and could hardly move his legs.

${ }^{68}$ Montaigne was completely his own master at the spas that he visited. At Plombières, for instance, he drank nine glasses a day instead of the customary two: see Montaigne, op. cit., note 6 above, p. 66.

69 "Elle a une attention pour moi, pareille à la vôtre". Sévigné, op. cit., note 10 above, vol. 8, p. 117: letter to her daughter, 9 October 1687.

70 The best introduction to the early modern French family is R. Pillorget, La Tige et le rameau. Familles anglaises et françaises $16^{e}-18^{e}$ siècles, Paris, Calmann-Lévy, 1979.

${ }^{11}$ Boileau, op. cit., note 14 above, p. 740: letter to Racine, 9 August 1687 . The chance acquaintance from the locality was the abbé de Sales.
} 


\section{The spa in seventeenth-century France}

In addition, most of the visitors at the French seventeenth-century spa were in poor health. If Mme de Sévigné and Boileau were scarcely at death's door, this was not the case with many who struggled to "take the waters" as a last resort. Mme de Sévigné was appalled by the sights that greeted her eyes at Bourbon. Most people, she declared, came to the spa by litter (she, it will be recalled, had had to walk much of the last stage of her journey). "Il y a ici des gens estropiés et à demi morts, qui cherchent du secours dans la chaleur bouillante de ces puits; ... une infinité de restes ou de menaces d'apoplexies: c'est ce qui tue." ${ }^{, 72}$ A world peopled by stretcher cases was scarcely likely to be one of vibrant sociability. Only hypochondriacs (like Mme de Sévigné) went to spa without due cause. The only visitors to popular spas who were in the pink were the attendants and servants in the bloated entourage of those close to the throne. Mme de Montespan travelled to Bourbon in 1676 in a coach and six accompanied by 45 attendants and horse-guards. ${ }^{73}$ Not surprisingly the healthy few were quickly bored. One of the difficulties of spending a long season at Barèges with the Duc de Maine, Mme de Maintenon was well aware, was that the domestics would quickly start agitating to return. ${ }^{74}$ No one wanted to stay at a French spa if they could help it.

Admittedly, the omnipresence of the sick and the preference for closed and affective social relations might be as much effect as cause of the monotonous character of life at the seventeenth-century spa. In the end, their exact role in the emergence of the institution does not matter. They are factors that strengthened the prevailing lacklustre ambience, if they were also, perhaps, its product. What can be said with certainty is that the French spa throughout the century remained the creature of its inventors: the medical profession. The pattern of existence at the spa followed closely the routine laid down by the spa physicians from the beginning of the century. Admittedly, the state conspired to make it difficult for the spa to become other than a hospice by placing such powers of control in the hands of the intendant and his associate physicians. Equally, the patients, especially the rich and noble, made it easier for the physicians to shape the institution in the manner that the profession desired by their deference, the physical state of decrepitude in which they arrived, and their "bourgeois" behaviour. Nevertheless, the French spa was the physicians' brainchild. The physicians wanted to create centres of therapy not sociability, and this they achieved. This is not to say that they did not seek profit in the enterprise. They certainly did, but they sought profit in a professional and (to them) medically honest manner, and the intendants sought it for themselves and their associates, not for the local town. This may have been short-sighted on their part, for it guaranteed that the institution had a limited market. There would be no eighteenth-century French Bath. But the intendants were university-educated professional men, not pioneering entrepreneurs. Charles Delorme was not Beau Nash. ${ }^{75}$

\footnotetext{
${ }^{72}$ Sévigné, op. cit., note 10 above, vol. 8, pp. 106, 107, 111 : letters to her daughter, 25 and 27 September, 1687.

${ }_{73}$ Sévigné, op. cit., note 10 above, vol. 4, p. 446: letter to her daughter, 15 May 1676.

74 Maintenon, op. cit., note 9 above, p. 386: letter to the Marquis de Montchevreuil, 20 June 1681.

${ }^{75}$ This idea of the entrepreneurial versus the professional ethic in the development of the spa in France and England is developed in my unpublished paper: 'Taking the waters in early-modern France. Some thoughts on a commercial racket'. Early drafts of this paper have been given to seminars at University College London, Christ's College, Cambridge, and the University of York.
} 


\section{W. B. Brockliss}

\section{SOME CONCLUDING THOUGHTS}

The main purpose of this article has been to outline the development and chief characteristics of the seventeenth-century French spa. In conclusion, it would be satisfying to go further and consider whether or not the French experience was representative. Unfortunately, given the present state of research into seventeenthcentury balneology, a comparative analysis is impossible. The history of the spa in the age of the Scientific Revolution has scarcely begun to be written. Indeed, there are certain aspects of even the French experience which require further exploration. To the best of my knowledge this is the first attempt to delineate the development of the French spa and there are inevitably lacunae in the picture presented.

For instance, nothing has been said so far about the consumption of bottled mineral water during the Grand Siecle. We know that this was a well-established practice in eighteenth-century France (as it was in England), but information about its seventeenth-century genesis remains too sketchy to be described with confidence. ${ }^{76}$ All that can be said for the moment is that the practice seems to date from some time in the third quarter of the century. This is known because there exists an undated royal edict from the period when Antoine Valot (d. 1671) was chief physician to Louis XIV granting a surgeon called Filesac sole right to import into the capital the waters of Sainte-Reine, Saint-Myon, Spa, and Forges. Now, Valot held his post from 1652 to $1671 .^{77}$ On the other hand, the first person definitely known to have consumed bottled mineral water in Paris or Versailles was Mme de Maintenon. When the latter was ill in 1681, Fagon arranged for her to be sent the waters of Sainte-Reine. ${ }^{78}$ Apparently, too, the consumption of bottled water in the last decades of the seventeenth century was not a simple alternative to attending a spa. In $1687 \mathrm{Mme}$ de Sévigné underwent an eight-day course of Vichy water while she was at Bourbon, and this was not in any way considered uncommon or novel. ${ }^{79}$ How significant the trade in bottled mineral water was by 1700 , however, is impossible to say. Certainly, it was large enough to begin to worry the spa doctors who presumably felt its increase could threaten their livelihood. Larouvière in 1699 pointedly ended his guide to Forges by questioning the wisdom of consuming its waters anywhere but on site. Once transported they lost their volatility and became little different from common water. ${ }^{80}$

Nevertheless, if it is out of the question here to make a definitive statement about the seventeenth-century French spa, it is possible to suggest several reasons why its

\footnotetext{
${ }^{76}$ Pascale Cosma-Muller, 'Entre science et commerce: les eaux minérales en France à la fin de l'ancien régime', in J. P. Goubert (ed.), La médicalisation de la société française 1770-1830, vol. 9 of Historical Reflections/Réflexions historiques, Waterloo, Ont., 1982, pp. 257-61; Macintyre, op. cit., note 55 above, pp. 171-7, 452-5 (on bottling the waters of Bath and Scarborough).

${ }^{77}$ Bibliotheque Nationale, MS Français 21738, fol. 423. Filesac also had the right to import other unspecified waters.

${ }^{78}$ Maintenon, op. cit., note 9 above, p. 362: letter to her brother, 2 March 1681.

79 Sévigné, op. cit., note 10 above, vol. 8, pp. 105, 107, 113: letters to her daughter, 25 and 27 September and 7 October. The waters of Vichy were brought in a day to Bourbon, where they were reheated. Apparently Fagon had had his wife drink Vichy water while at Bourbon. Mme de Sévigné seems to have also drunk Vichy water in the capital.

80 Larouvière, op. cit., note 16 above, pp. 244-5. Fouet, op. cit., note 34 above, pp. 101-5, attacked the transportation of Vichy water as early as 1679 , but he seems to have been merely attacking the custom of bottling the water for the use of local people, e.g. religieuses confined to a convent.
} 


\section{The spa in seventeenth-century France}

history should be further researched (indeed, the history of the early-modern spa tout court).

In the first place, in France at least the spa played a definite role in the dethronement of Galenism as the establishment medical orthodoxy. As was said at the beginning of the article, the sixteenth-century promotion of the spa in Europe north of the Alps was chiefly the work of Paracelsians. This was inevitable because orthodox Galenists were automatically suspicious of a therapy about which Hippocrates and Galen had little to say and whose utility seemed to extend to all diseases and individuals regardless of their temperament. French Galenists at the turn of the seventeenth century, then, attracted by the market potential of a remedy now championed at court, had first to convince themselves and their colleagues in the medical profession that the spa was ideologically sound. This was no easy task and indeed a defence that satisfied the entire medical establishment was never successfully formulated. Although the authors of the first spa guides insisted on the impeccable classical credentials of the spa and tried to explain the therapeutic action of the hot or cold spring in allopathic terms, they were always forced to admit that their defence was imperfect. Because of the deficiencies in contemporary chemical analysis, no one knew exactly the mineral composition of the waters being promoted. Guesses might be made from their taste or smell, but essentially their composition was known from their effects. Bourbon water seemed to cure palsy, paralysis, ulcers, and excessive menstruation. As these were diseases which would respond to treatment by sulphur and bitumen Cattier was certain in 1650 that the evidence of the senses was correct and it was indeed sulphur and bitumen that the water contained. ${ }^{81}$ In addition, Galenist promoters were always aware, however much they insisted that different stations should be visited for different complaints, that cures were frequently effected (or were claimed to have been) at particular spas that could in no way be expected according to the waters' temperature and putative composition. This could only be explained by recourse to the Fernelian distinction between the manifest and the occult. The properties of many natural phenomena lay hidden to reason but could be known through experience. Once it was accepted that there was something "divine" contained in mineral water, then the apparent irrationality of its action became comprehensible. $^{82}$

Many orthodox Galenists found this ultimate reliance on experience unacceptable. Being Galenists they instinctively distrusted therapies that could not be justified in terms of rational first principles. But this distrust was heightened by their belief that the monopoly of the established medical profession was under attack in the first half of the seventeenth century from a motley assortment of empirics, chemists, and Paracelsian fellow-travellers who used just such claims from experience to justify a wide variety of novel and irrational remedies. Recourse to the spa on experiential grounds was just as heinous as recourse to antimony. In consequence, die-hard Galenists launched a bitter attack on "taking the waters" as part of their general

\footnotetext{
81 Cattier, op. cit., note 16 above, ch. 4.

82 E.g., the argument in Auberi, op. cit., note 4 above, bk. ii, chs. 12 and 13. Jean Fernel (1485-1558) set out his theory of the occult in De abditis rerum causis Libri duo, 2nd ed., 1551, Paris, Jacques Dupuys.
} 


\section{W. B. Brockliss}

denunciation of "empirical" remedies. Honest Galenic physicians, they argued, should only use cures whose operation they understood. The die-hards were led by a powerful section of the hundred-strong Paris medical college who for nearly 40 years after 1630 (by which date "taking the waters" had definitely become a fashionable cure) tried in vain to prevent their colleagues from deploying any form of mineralbased therapy ${ }^{83}$ The attack became all the more envenomed in that graduates of the Montpellier faculty used the opportunity of this principled stance to accuse the Paris college of medical conservatism and to demand that the college admit graduates other than those of the Paris faculty. ${ }^{84}$

The die-hards' stance, it should be said, was a brave one, given that in the 1630s the king, the queen, and Cardinal Richelieu "took the waters". The Paris student Jean Pietre must have been a political innocent when he attacked in a graduate dissertation the deployment of mineral waters in the very year, 1633, that the court paid its first visit to Forges, even if he did limit his specific critique to diseases associated with "humorum aestus". Visceral complaints, he asserted, were made worse by "taking the waters", for the minerals contained were too hard and would only destroy native heat. ${ }^{85}$ Not surprisingly the riposte was not long in coming and the following year a wisely sycophantic Paris graduand, François Le Vigneron, dedicated a defence of mineral-water therapy to the king's chief physician, Charles Bouvard (c. 1572-1658), who had been responsible for sending his royal master to Forges. ${ }^{86}$

The result of this internecine quarrel over the use of metallic remedies was highly detrimental to the Galenist cause. At the very moment when alternative physical philosophies were being developed by Descartes and Gassendi, the Galenists became embroiled in an internal feud which turned their attention completely away from the enemy without. It is interesting to discover that Gui Patin (1601-72), one of the leading supporters of rational Galenism, made virtually no reference to Descartes in his correspondence, although his letters are full of details about the iniquitous behaviour of his experientialist colleagues. ${ }^{87}$ Moreover, the quarrel highlighted the fragility of Galenism as a medical philosophy. As the opponents of "taking the waters" made crystal clear and its supporters reluctantly accepted, Galenic principles

\footnotetext{
${ }^{83}$ Both "experiential" and "rational" Galenism are discussed in detail in L. W. B. Brockliss, "Seeing and believing. Contrasting attitudes towards observational autonomy among French Galenists in the first half of the seventeenth century', in W. F. Bynum and R. Porter (eds.), Medicine and the five senses (forthcoming, Cambridge University Press). A short account of the quarrel over the use of mineral remedies in the Paris faculty can be found in L. W. B. Brockliss, 'Medical teaching at the University of Paris, 1600-1720', Anns. Sci., 1978, 35: 239-45.

84 See idem, 'La querelle', op. cit., note 22 above. This supersedes all earlier accounts of the conflict, of which the best available in English is Howard M. Solomon, Public welfare, science and propaganda in seventeenth century France. The innovations of Théophraste Renaudot, Princeton University Press, 1972, esp. ch. 6.

${ }^{85}$ Jean Pietre, 'An visceribus nutritis aestuantibus Metallicarum aquarum potus, salubris?' (negative), 1633, in Bibliothèque de la Faculté de Médecine, Paris, Theses medicae parisiensis in-fol., vol. 4, no. 790.

${ }^{86}$ François Le Vigneron, 'An calidis naturis qualiumque Metallicarum aquarum potus insalubris?' (negative), 1634, in ibid., no. 798.

${ }^{87}$ Gui Patin, Lettres, ed. J. H. Réveillé-Parise, 3 vols., Paris, J. H. Baillière, 1846. Descartes was mentioned in just two letters from 1669 and 1672, and then en passant.
} 
could not effectively explain the therapeutic properties of a cure whose efficacy was enthusiastically confirmed by the unimpeachable witness of many among the great and good. The waters of Forges had given the country Louis XIV. To be unable to explain their action may have helped enhance the divine status of the future Sun King in the popular mind, but it only helped to devalue Galenism as a medical philosophy in the eyes of mid-seventeenth century Paris salon society.

In the second place, the seventeenth-century French spa is of interest for the light it sheds on the concept of the "patient". In recent years the attention of medical historians of early modern Europe has begun to focus on patient-practitioner relations. The picture that seems to be emerging for England is that, at least until the end of the eighteenth century, the sick were not patients in the modern sense of the term. In the case of the well-to-do and educated in particular, the patient had as much medical knowledge as the practitioner, could and did make his own judgements as to his illness, and had the freedom to consult whom he pleased on the matter (trained or untrained) ${ }^{88} \mathrm{~A}$ study of the seventeenth-century French spa suggests, however, that in one European state the modern concept of the patient was emerging at an earlier data. Those who "took the waters" in the reign of Louis XIV, be they La Montespan or a humble artisan, were subjected for intervals of two weeks to two months to a highly regimented existence laid down by a spa doctor. Indeed, the existence was not only regimented but humiliating. Mme de Sévigné's disgust at being naked in the shower was presumably shared by all other ladies of quality. But the rich and famous did not have to be ordered to undress to suffer a loss of dignity. Ladies who were forced to rise at an early hour and drink at the fountain may have been physically clothed. Nevertheless, they were decidedly deshabillees, as it was only after they had drunk their dose that their coiffure was attended to. In fact, they came to the fountain at Forges without even combing their hair. ${ }^{89}$

Of course, not everyone who went to the spa put themselves unreservedly in the doctor's hands. Had this been the case, then there would have been no need for the authors of spa guides throughout the century to reiterate the importance of seeking and obeying medical guidance. Ideally nobody visited a spa unless they had been referred there by a physician, and they came equipped with a written account of their medical history that was to be presented to the spa doctor. Quite clearly, however, visitors still came on their own initiative even at the end of the century. Larouvière, promoting Forges in 1699 , treated the independent visitor as a common occurrence. ${ }^{90}$ Clearly, too, some visitors always ignored the professional advice that the spa doctor offered. Larouvière offered to his readers as a salutary warning against disobedience the unhappy case of an English gentleman who had visited Forges in 1699 (the nationality of the miscreant was doubtless not accidental!). Forges water had to be

\footnotetext{
${ }^{88}$ See the essays in Roy Porter (ed.), Patients and practitioners. Lay perceptions of medicine in pre-industrial society, Cambridge University Press, 1985, esp. Porter's introduction; also Andrew Wear, 'Medical practice in late seventeenth and early eighteenth-century England: continuity and union' in Roger French and Andrew Wear (eds.), The medical revolution of the seventeenth century, Cambridge University Press, 1989, ch. 11.

${ }^{89}$ Larouvière, op. cit., note 16 above, p. 196.

${ }^{90}$ Ibid., pp. 182-3. It is possible that Mme de Sévigné went to Bourbon in 1687 on her own initiative.
} 


\section{W. B. Brockliss}

drunk in small quantities (as was earlier noted) and slowly. The English milord, however, "en presence des quelques Dames de son païs, avala 12 ou 13 verres d'eau de la Cardinale [reputed the strongest of the three springs], si brusquement, qu'il fut 18 heures sans pouvoir en rendre une goute, souffrant des douleurs extraordinaires". Larouvière's valiant attempts to relieve the unfortunate bon buveur's repletion initially failed. To no avail, the Englishman was given eau-de-vie and two lavements, then bled and given three hot baths. He rendered the waters only after the administration of a timely emulsion. ${ }^{91}$

On the other hand, what is more remarkable is the degree of definite compliance. Significantly, Mme de Sévigné, who herself obeyed her doctors at Vichy and Bourbon without question, called Bourbon in 1687 a convent. Everybody at the spa did the same thing at the same time in the same way. ${ }^{92}$ Compliance, moreover, extended beyond the hypochondriacal and the acutely sick (so common at Bourbon) to the cynical and merely off-colour. Boileau, it will be recalled, believed that the doctors (both at Paris and Bourbon) did not understand his malady. His jaundiced opinion of the medical profession was only enhanced when the physicians began to quarrel among themselves over his case. Bourdier, to whose care he had entrusted himself, believed that Boileau should drink but not bathe. Fagon (orchestrating the cure from Versailles) and Amyot believed that he should do both. Boileau understandably lamented his fate to his friend, Racine. "A vous dire le vrai, mon cher Monsieur, c'est quelque chose d'assés fascheux que de se voir ainsi le jouet d'une science trés conjecturelles et ou l'un dit blanc et l'autre noir." Nevertheless, and this is the crucial point, Boileau was resigned. "Mais enfin me voila livré à la Medicine et il n'est plus temps de reculer." By the end of his stay, Boileau came to see his sojourn at the station not as a cure but a penance: "je m'en vais regarder dorenavant les eaux et les medecines que j'avalerai comme des penitences qui me sont imposées plûtost que comme des remedes qui doivent produire ma santé."93 Once more Bourbon had been turned into a convent. It had become a place of pilgrimage, retreat, and suffering where obedience was demanded by God. ${ }^{94}$

This is not to say that the large majority of the French élite in the reign of Louis XIV were deferential and obedient to the wishes of their physicians. On the contrary, the evidence is overwhelming that people of quality from the king down took their own medical decisions. When Louis XIV was suffering from the famous fistula in 1686, he was advised by his physicians to take the waters at Barèges, which had supposedly worked wonders for his bastard son, the Duc de Maine. Louis XIV, however, was a wily bird. His minister Louvois ordered a number of his subjects suffering from a similar disability to be sent to the spa first. When they showed no signs of improvement, the king sensibly declined to suffer the discomfort of the long journey to the Pyrenees. ${ }^{95}$ Even hypochondriacs like Mme de Sévigné refused to be patients away from the spa. La Sévigné believed totally in her own ability to diagnose

${ }^{91}$ Ibid., pp. 215-6.

92 Sévigné, op. cit., note 10 above, vol. 8, p. 111: letter to her daughter, 27 September.

93 Boileau, op. cit., note 14 above, pp. 742-3: letter to Racine, 13 August.

94 Ibid., p. 786: letter to his sister, 31 July.

95 John B. Wolf, Louis XIV, London, Gollancz, 1968, p. 351. 


\section{The spa in seventeenth-century France}

her maladies and in her search for the perfect medical practitioner changed her doctors almost as often as she and her society friends changed their clothes. Her trust in her medical advisers was absolute but always temporary and conditional, and she was more than ready to patronize the unqualified quack. Interestingly, her visit to a spa in 1676 was under doctor's orders but the choice of Vichy was her own. "[Delorme] veut Bourbon," she wrote to her daughter, "mais c'est par cabale [she was right]; ainsi je suivrai les expériences qui sont pour Vichy."96

The power of the spa physician, then, should not be seen as an expression of modern patient-practitioner relations avant la lettre. But it is no less significant for that. Such a concrete example of medical "tyranny" offered a tempting vision of the possibilities of far greater professional influence, which future generations of Enlightenment physicians would seek to imitate and translate into their daily practice. ${ }^{97}$ No professional group, conscious of its value but treated in the main as the lackeys of the rich, could be expected to turn its back on this alternative model of the physician as a figure of power and dignity. ${ }^{98}$ It becomes important, therefore, that much more is known about the relationship between the spa physician and his clients, not just in France but all over Europe. It may be that the situation in France was peculiar. The controlling power of the intendant, the distance of the leading spas from Paris and Versailles, the presence of so many chronically sick, all were factors that helped develop practitioner-power. However, until a full comparative study is made, the "invention" of the patient in seventeenth-century France cannot even be begun to be understood. 99

Finally, the history of the seventeenth-century French spa is of interest for the insight it offers into what has been dubbed the "civilizing process". However much the structure of the spa itself may have promoted the creation of the patient, there can be no doubt that the phenomenon would have been impossible without a concomitant revolution in the general behaviour of the French élite. At the end of the sixteenth century the majority of the French nobility (both men and women) were insubordinate, violent, licentious, boorish (many could hardly sign their names), and

\footnotetext{
${ }^{96}$ Sévigné, op. cit., note 10 above, vol. 4, pp. 419-20. The Marquise's attitude towards physicians is discussed in Brockliss, op. cit., note 31 above.

97 The Enlightenment interest in the creation of a practitioner-led medicine will be discussed in a book on the seventeenth- and eighteenth-century French medical profession presently being prepared by the author and Dr Colin Jones.

98 From at least the late sixteenth century French physicians saw their profession as a highly honourable, spiritual calling. Arguably, what they lacked before the development of the spa was an institution in which they could enjoy in reality a priestly authority. For an early example of such rhetoric, see Jean Liebaut, Quatre livres des secrets de medecine, et de la philosophie chimique, Rouen, chez Théodore Reinsart, 4596[?], dedicatory epistle of 1573. Liebaut was a graduate of the Paris faculty. As the title of this work emphasizes, this elevated concept of the médecin was promoted initially by physicians under the influence of Paracelsus, who himself had championed the idea.

99 Admittedly, the development of the spa was not the only factor encouraging the invention of the "patient" towards the end of the seventeenth century. If Saint-Simon is right, then once Fagon became chief physician to the king, Versailles ceased to be a medical marketplace and the premier médecin had absolute sway over the treatment of the royal family and courtiers who fell sick. As the court set the tone for the rest of French élite society, this change, if real, must have been significant, even if the power of the chief physician was not maintained by Fagon's successors: see Brockliss, op. cit., note 31 above, pp. 133-43.
} 


\section{W. B. Brockliss}

incapable of self-control. Only the small group of ennobled officiers (often only a single generation away from the urban bourgeoisie) showed a limited enthusiasm for the code of self-constraint preached by the humanists and neo-stoics. Over the course of the seventeenth century, however, a revolution occurred in the behaviour of the French élite that would make the eighteenth-century French aristocrat a byword for civilized conduct. Essentially, the French nobleman learnt to control himself and be controlled: the frondeur of the Wars of Religion and the first half of the seventeenth century became the courtier of the Versailles of Louis XIV. ${ }^{100}$

Why this revolution came about has never been really explored, except by the German sociologist Norbert Elias, who was interested in the significance of the change for the development of the absolute state. Elias believed that the change should be seen as the nobility's response to the growing numbers, wealth, and importance of the French bourgeoisie. As the bourgeoisie began to ape the consumption patterns and habits of the aristocracy, so the latter attempted to retain their separate identity by developing ever more sophisticated forms of behaviour. ${ }^{101}$ This is a fruitful idea and helps to explain why the change in behaviour should have been a pan-European, not just a French phenomenon. Nevertheless, Elias fails to identify the mechanics of the process by saying nothing about the institutional means through which this new code of conduct was internalized. Without the presence of a set of institutions in seventeenth-century France geared consciously or unconsciously to the promotion of this new aristocratic mentalité, the revolution would have been impossible, however much welcomed by the Counter-Reformation Church and the state. One crucial institutional intermediary was the college de plein exercie, the training-ground of the legal, administrative, and ecclesiastical élite. ${ }^{102}$ Another was the professional standing army created by Le Tellier and Louvois, a new type of armed force dedicated to iron discipline and co-operation. ${ }^{103} \mathrm{~A}$ third was obviously Versailles itself. These and other institutions all played a part in creating a tame noble caste and thereby, in the context of this paper, made practitioner-led medicine possible. There could be no patients among the rich and powerful before the élite had learnt patience.

However, it would be wrong to see the physicians' power at the spa in the age of Louis XIV as a mere reflection of this behavioural revolution. The seventeeenthcentury French spa was also a part, albeit a peripheral one, of the "civilizing process"

\footnotetext{
100 Of course, only a small proportion of the French nobility ever actually lived at Versailles. But the court, and especially the behaviour of the king, set the tone.

${ }_{101}$ Norbert Elias, The civilizing process, 2 vols., Oxford, Blackwell, 1978-82; idem, The court society, Oxford, Blackwell, 1983. The summation does not do justice to the richness of Elias's argument, which examines the growth and effect of "civilized" behaviour over many centuries. Historians of the French absolute state have virtually ignored the role of behavioural change in the augmentation of royal power, preferring to explain the power of Louis XIV in terms of the sophistication and size of the royal bureaucracy: cf. the critical comments of William Beik, Absolutism and society in seventeenth-century France: state power and provincial aristocracy in Languedoc, Cambridge University Press, 1985, ch. 1.

${ }^{102}$ See G. Snyders, La pédagogie en France aux XVIF et XVIIF siècles, Paris, Presses Universitaires de France, 1965, esp. bk. i, ch. i; also L. W. B. Brockliss, French higher education in the seventeenth and eighteenth centuries: a cultural history, Oxford University Press, 1987, esp. pp. 449-51.

${ }^{103}$ The best study on the French army is A. Corvisier, L'Armée française de la fin du XVIIe siècle au ministère de Choiseul, le Soldat, 2 vols., Paris, Presses Universitaires de France, 1964.
} 
itself. As Boileau observed, attendance at the spa was a penance, a short, sharp reminder to those who had failed to regulate their life-styles in the approved fashion. It was a refresher course in obedience for those for whom obedience was becoming perfunctory. Indeed, it might almost be said that the health of the absolute state demanded that a proportion of the élite "took the waters" each year. Whether Louis XIV realized the potential of the institution and actively encouraged his courtiers to spend their summer vacations at a spa rather than idling on their estates unfortunately will never be known. It is tempting to believe that he did and to see his physicians sending their noble clients off to Bourbon or Forges on the orders of their royal master for political as well as medical reasons. Did, then, Madame de Sévigné meditate on the will of the Sun King, as nearly naked she suffered the heat and power of the Vichy douche? Or, indeed, the sublimation complete, did she believe herself the actual recipient of the royal touch which could both hurt and heal? If she did, the great letter-writer said nothing about it to her daughter, but there again she lived in an age of innocence that had not yet discovered the unconscious. ${ }^{104}$

\footnotetext{
104 This final thought is not pure authorial fancy. Madame de Sévigne was devoted to the king but she had an unhappy knack of choosing political losers as her friends. These included the family of the disgraced surintendant des finances, Fouquet, and Madame de Sévigné actually stayed with Madame Fouquet at Moulins on her way to Vichy in 1676: Sévigné, op. cit., note 10 above, vol. 4, p. 451: letter to her daughter, 17 May.
} 